\title{
Impact of Official Development Assistance on the Growth of WAEMU Member Countries: Assessment Following the Recommendations of the 2002 Monterrey Conference
}

\author{
Bayoko Lacine
}

Faculty of Economic and Management Sciences, Felix Houphouet Boigny University of Abidjan

Doi: $10.2478 / \mathrm{mjss}-2018-0007$

\begin{abstract}
This paper evaluates the impact of official development assistance on the growth of WAEMU countries using an econometric approach. This assessment heeds the recommendation of the 2002 Monterrey Conference that diversification of development support resources is needed. The results obtained indicate that the total net public assistance received has a positive and significant impact in the short and long term on the growth of WAEMU countries. By diversifying the development support resources of the zone, the minimum threshold of official development assistance needed to boost the growth of the countries of the zone is $13.5 \%$ of GDP per capita.
\end{abstract}

Keywords: Official development assistance, Economic growth, Domestic savings, Foreign Direct Investment (FDI), causality, Cointegration, threshold effect.

\section{Introduction}

In March 2002, following the International Monitoring Conference on Financing for Development, in Monterrey, Mexico, important recommendations were made, including the issue of diversification of development support resources. It was found that official development assistance was no longer sufficient to finance the development of beneficiary countries because of the various constraints faced by donors. Two categories of resources have been recommended for this purpose. It's about:

- Domestic savings to be collected from the public administration and the private sector and allocated to socially productive investments;

- Foreign Direct Investment (FDI) and other private capital flows identified as attracting resources to finance development.

The recommendation of the Monterrey conference in such a context raises the question of the effectiveness of official development assistance in terms of growth. Indeed, the mobilization of domestic savings for investments remains a problem in space despite the state of over-liquidity found in the area. In addition, of the poverty, most households find it difficult to save. Moreover, although the WAEMU area benefits from large foreign direct investment, this area of sub-Saharan Africa is subject to capital flight (N'diaye, 2009). The question arises as to whether the application of the recommendation in the WAEMU zone is based on the conflicting trends of the incoming and outgoing recommended flows.

The general objective of this paper is therefore to assess the impact of official development assistance on the growth of the WAEMU countries, taking into account the policy of diversification of resources recommended by the Monterrey Conference. 


\section{Literature Review}

The effectiveness of aid for growth has been the subject of several studies. All these studies resulted in three main results, to know:

- Aid does not affect growth and may even slow it down,

- The relationship between aid and growth is generally positive;

- The relationship between aid and growth is conditional.

Griffen and Enos (1970) were among the first to question the effectiveness of aid, based on an empirical study of a simple negative correlation between aid and growth in 27 countries. Many researchers have reflected on this conclusion, arguing that the relationship was delicate or nonexistent (Mosley and Allis 1987, Dowling and Hiemenz 1982, Singh 1985, Booe 1994). For Peter Bauer (1972), aid is detrimental to the private sector and hinders development because it acts as a disincentive to investment. The study by Boone (1994), in particular, is one of the most cited in this field. His analysis focused solely on a linear relationship, thus disregarding the possible endogeneity of aid, and concluded that aid affects growth negatively. As for Voivodas (1973), who worked on a sample of 22 countries over the period 1956-1968, the aid-growth relationship would be rather insignificant. For this category of researchers, aid would not promote growth for several reasons including governance (embezzlement).

In the mid-1990s there was a significant shift in direction when supporters began to question whether aid could stimulate growth and whether its output could decline as aid grew. Indeed, until the mid-1990s, those interested in aid effectiveness tested only a linear relationship between aid and growth, which poses the problem of endogeneity linked to The use of a single equation in which the reverse effect of low growth on a massive allocation of aid is ignored. These inadequacies were subsequently identified by a new category of researchers who will support the contrary view.

Most of these authors acknowledge the decreasing returns to aid and conclude that they are positively related to growth (Hajimichael et al., 1995, Durbarry et al., 1998, Dalgaard and Hansen 2000, Hansen and Tarp, 2000 and 2001. Lensink and White, 2001.

Dalgaard et al., 2004). According to the majority of these researchers, aid has not always been effective. But, in general, the increase in aid flows has been associated with faster growth. The relationship is generally positive, although returns decline as aid increases, that is to say the marginal impact on growth is maximized when aid is lower and declines as aid increases.

In addition to these global studies, some studies have focused specifically on the case of subSaharan African countries. One is the one by Levy (1988), which concluded that aid has a positive and significant impact on growth in these countries. However, it should be noted that its estimate on cross-sectional data covers only the period 1968-1992. More recently, Hadjimichael et al. (1995)

Same results on a sample of 41 countries over a period from 1986 to 1992. Despite the abundant empirical literature on aid-growth, studies have not directly addressed the mechanisms on which aid can affect growth. Karima Gomanee, Sourafel Girma and Oliver Morrissey (2005) identify investment as the most significant transmission mechanism and also consider effects through import financing and government consumption expenditure. On a Panel of 25 countries in sub-Saharan Africa during the period 1970-1997, the results of the estimate show a significant and positive effect of aid on growth.

Our approach, unlike all of these studies, will be to assume that investment for growth in the WAEMU zone is fueled by the various resources recommended by the Monterrey conference. This investment will be disaggregated according to the different resources recommended.

\section{Modeling and Source of Data}

\subsection{Choice of model variables}

The work of TENOU (1998) on the determinants of growth in WAEMU countries will be used to determine the active variables of growth in this zone. These variables are commonly used in longrun real growth models and can be divided into three categories: conventional variables, variables related to economic policy and variables related to the external environment. 
In theoretical models, private and public investment (in physical capital) is a key conventional variable of growth. For this study, foreign direct investment (IDE) will be used to test its impact on economic growth. The choice of this indicator is motivated by the recommendation made at the Monterrey conference and by the fact that, in the models of endogenous growth (Romer, 1986), investment has a positive effect on the productivity of other firms in the Technology transfers. The assumption that growth originates in investment will then be accepted as part of this study.

External debt and official development assistance will be the economic policy variables used in the growth function estimate. External debt will be approached by a vulnerability indicator to measure the risk that current country conditions may undermine debt status. The external debt-toGDP ratio will be used to capture this vulnerability in the WAEMU countries. This indicator measures the level of indebtedness relative to a country's economic activity. It is currently considered the most important to measure the degree of indebtedness, indicating the solvency capacity of the Government.

Official development assistance to GDP will be introduced into the model in order to determine its impact on economic growth. This will make it possible to seek an optimum of the public aid needed to boost the economic growth of WAEMU countries.

Domestic saving and private aid are two important variables for developing countries in the study of economic growth in the light of the recommendation made at the Monterrey Conference. Indeed, the conference advocated that domestic savings be collected from the government and the private sector and that the private sector be allocated to socially productive investments.

Foreign Direct Investment (FDI) and private capital flows have been identified as attracting resources to finance development. Private capital flows will be approached by private development assistance as a share of GDP in this study.

The variable for the external environment is characterized by the rate of opening. Thus, the vulnerability of a country facing the outside will be perceived by a negative sign of the coefficient of this variable, otherwise, opening to the outside leads to growth.

\subsection{Specification of the econometric model}

The model to be analyzed finds its theoretical foundation of a Cobb Douglas production function in its linearized form as follows:

$Y_{t}=A+\alpha K+\beta h(1)$

Physical capital per capita (k) is represented by the investment rate (inv), while human capital (h) appears in the model through the population effect shown in the growth indicator National income per capita: (nipc). As for technical progress, it is dependent on human capital and its quality, so it appears implicitly in the model

Moreover, taking into account the active variables of growth within the WAEMU and the objectives of this study, it has been found pertinent to introduce control variables in order to obtain an increased growth model. The equation obtained is thus as follows:

$$
\operatorname{nipc}_{i, t}=\beta+\varphi \operatorname{oda}_{i, t}+\delta o d a_{i, t}^{2}+\gamma d e b t_{i, t}+\omega_{p d a_{i, t}}+\mu \operatorname{sav}_{i, t}+\sigma f d i_{i, t}+\operatorname{\theta open}_{i, t}+\varepsilon_{i, t}
$$

Where by country $\mathrm{i}$, (nipct) is the national income per capita at time $t$. (fdit) corresponds to foreign direct investment. (Debt $)$ corresponds to the debt burden, while (oda $\mathrm{t}_{\mathrm{t}}$ ) is the official development assistance and (odat ${ }^{2}$ ) its square fed into the growth model to find an optimal threshold of necessary public support to boost the growth of WAEMU countries. $\left(p^{2} a_{t}\right)$ and $\left(\operatorname{sav}_{t}\right)$ respectively represent private development aid and domestic savings. (opent $n_{t}$ ) is the open rate, the variables to assess the dependence of WAEMU countries with respect to the exterior.

\subsection{Presentation of the "ARDL Panel cointegration" method}

To examine the long-term relationship between economic growth and official development assistance and other resources recommended by the Monterrey conference in WAEMU, we will use the panel approach to use the cointegration test approach Developed by Pesaran and al (2001) applied to Auto Regressive Distributive Lags (ARDL) models. This approach has many advantages and does not necessarily require that the variables of the model be purely I (0) or I (1). The model 
can be applied in a situation where both I (0) and I (1) variables are found. The approach is particularly appropriate for studies where the samples are small. In addition, panel data will help to address much more ambitious concerns in the econometric analysis, especially when dealing with the interconnection of several economies.

The strategy for implementing the ARDL panel cointegration test follows two steps. In the first step, we will determine the ARDL model (it is an unconstrained error correction model) from the basic equation as follows:

$$
\triangle N I P C_{i, t}=\alpha_{0}+\sum_{j=1}^{p} \beta_{j} \Delta N I P C_{i, t-j}+\sum_{j=0}^{q} \gamma_{j} \Delta O D A_{i, t-j}+\sum_{j=0}^{r} \delta_{j} \Delta O D A_{-} 2_{i, t-j}+\sum_{j=0}^{s} \lambda_{j} \Delta D E B T_{i, t-j}+
$$

$\sum_{j=0}^{m} \varphi_{j} \Delta P D A_{i, t-j}+\sum_{j=0}^{n} \omega_{j} \Delta S A V+\sum_{j=0}^{v} \rho_{j} \Delta F D I_{i, t-j}+\sum_{j=0}^{h} \theta_{j} \Delta O P E N_{i, t-j}+\pi_{1} N I P C_{i, t-1}+\pi_{2} O D A_{i, t-1}+$

$\pi_{3} O D A_{-} 2_{i, t-1}+\pi_{4} D E B T_{i, t-1}+\pi_{5} P D A_{i, t-1}+\pi_{6} S A V_{i, t-1}+\pi_{7} F D I_{i, t-1}+\pi_{8} O P E N_{i, t-1}+\varepsilon_{i, t}$

Then we will determine, through the information criteria, the optimal delay by estimating the ARDL model. The second step consists in finding the optimal ARDL model by combining all the possibilities for the delays of each variable and then testing the cointegration.

Testing cointegration by the Pesaran et al (2001) approach in ARDL models amounts to testing the overall significance of the coefficients of the variables in level from the WALD test: $\mathrm{HO}: \pi_{\mathrm{i}}=0 \forall \mathrm{i}=1, \ldots, 8$

Since the test statistic does not follow a standard law, two (2) critical values of the test statistic are provided by Pesaran et al. The first (the lower bound) is computed assuming that all the explanatory variables are I (0), the second (the upper bound) assumes them all I (1). The decision criterion is as follows:

There is cointegration when the calculated F-stat is greater than the critical upper bound. There is no Cointegration if the calculated F-stat is less than the critical lower limit. When the calculated statistic is between the two critical values, we can't conclude. The study of stationarity will determine the order of integration of the series before the implementation of the cointegration test.

\section{Sample Presentation and Data Sources}

To conduct this study, a sample of seven (07) WAEMU countries (Benin, Burkina Faso, Côte d'Ivoire, Mali, Niger, Senegal and Togo) was selected. The cruel lack of long series for Guinea Bissau is the main reason for the exclusion of this country in the sample. The variables of external indebtedness and the domestic saving of the countries come from the data of the base "edenpub", put on line by the BCEAO. The openness rate and gross national income per capita are mainly from the World Development Indicator (WDI) 2015 of the World Bank and the IMF. Data on official development assistance and private aid are those of the OECD. Data on FDIs were obtained from the UNCTAD website.

\section{Estimation the Model and Interpretations}

The econometric approach adopted breaks down into three (3) stages. First, the homogeneity test is carried out to check whether the nature of the data permits panel-type processing. Then, to avoid making "fallacious" estimates, the stationarity tests are applied to all the variables involved in the study. This part finally ends with the estimates and the tests written on the ARDL models.

\subsection{Homogeneity and unit root test}

The result for the homogeneity test according to the Hsiao procedure is as follows:

\begin{tabular}{ccc}
\hline Fisher & Critical Value & P-Value \\
\hline F1 & 1.0506333 & $0.3968334^{*}$ \\
F2 & 0.78720321 & $0.83269398^{*}$ \\
F3 & 0.41435323 & $0.99975729^{*}$ \\
\hline
\end{tabular}

Note:** Rejection of the null hypothesis at the $5 \%$ threshold

Source: Author under Stata 12 
From this table, it can be seen that the structure of the data generating process allows a processing in panel data. It is then appropriate to proceed to the next step, that is to say the unit root test of the variables of the model.

\subsection{Unit root test}

The results of the unit root tests are presented in Tables 1 and 2. The test statistics of Im, Pesaran and Shin and those of the Levin, Lin and Chu test allow to accept the null hypothesis of nonstationarity at the threshold of $5 \%$ In level in the WAEMU zone for the following variables: RNBHBT, DETT, IDE and OUV. On the other hand, these tests make it possible to reject the hypothesis of non-stationarity for the other variables at the $5 \%$ threshold. (APD, APD_2, APN and EPARG).

Table 1: Unit root test (at level)

\begin{tabular}{|l|c|c|c|c|}
\hline \multirow{2}{*}{} & \multicolumn{2}{|c|}{ Im-Pesaran-Shin Test } & \multicolumn{2}{c|}{ Levin-Lin-Chu Test } \\
\cline { 2 - 5 } & Constant & Constant+trend & Constant & Constant+trend \\
\hline NIPC & 1.0000 & 0.9993 & 1.0000 & 0.9400 \\
\hline ODA & 0.0325 & 0.0081 & 0.0346 & 0.0266 \\
\hline ODA_2 & 0.0028 & 0.0016 & 0.0047 & 0.0059 \\
\hline DEBT & 0.9682 & 0.1242 & 0.9382 & 0.0190 \\
\hline PDA & 0.0000 & 0.0004 & 0.0006 & 0.0213 \\
\hline SAV & 0.0004 & 0.0000 & 0.0019 & 0.0008 \\
\hline FDI & 0.9985 & 0.9877 & 0.9988 & 0.9995 \\
\hline OPEN & 0.3807 & 0.6125 & 0.5260 & 0.2658 \\
\hline
\end{tabular}

Note: P-values are carried forward. A P value less than 0.05 indicates that the non-stationarity hypothesis can be rejected at the threshold of $5 \%$

Source: Author, under stata 12

After the first differentiation, the tests allow to reject the hypothesis of non-stationarity for variables at the $5 \%$ threshold. It follows that the variables RNBHBT, DETT, IDE and OUV are I (1) while the variables APD, APD_2, APN and EPARG are I (0).

Table 2: Unit root test (in difference)

\begin{tabular}{|c|c|c|c|c|}
\hline & \multicolumn{2}{|c|}{ Im-Pesaran-Shin Test } & \multicolumn{2}{|c|}{ Levin-Lin-Chu Test } \\
\hline & $\overline{\text { Constant }}$ & $\overline{\text { Constant+trend }}$ & Constant & $\overline{~ C o n s t a n t+t r e n d ~}$ \\
\hline NIPC & 0.0000 & 0.0000 & 0.0000 & 0.0000 \\
\hline ODA & $\cdots$ & $\cdots$ & $\cdots$ & $\ldots$ \\
\hline ODA_2 & & & & \\
\hline DEBT & 0.0000 & 0.0000 & 0.0000 & 0.0000 \\
\hline $\begin{array}{l}\text { PDA } \\
\text { SAV }\end{array}$ & $\cdots$ & $\cdots$ & $\ldots$ & $\cdots$ \\
\hline FDI & 0.0000 & 0.0000 & 0.0000 & 0.0000 \\
\hline OPEN & 0.0000 & 0.0000 & 0.0000 & 0.0000 \\
\hline
\end{tabular}

\section{Empirical Results and Interpretations}

\subsection{Result of estimates}

The results of the estimates were obtained by including dummy variables for each country in the data panel considered. Indeed, this implies that all the countries of the panel considered possess specific structural characteristics and have been subjected to different shocks. Thus the structural differences between the countries of the panel affect the variable of interest [National income per 
capita].

Estimates are made by selecting the optimal order of the ARDL model using the generalspecific (GS) test strategy used by Ozanne in his article in 2006. This testing strategy was suggested by Campbell and Perron (1991) And Hall (1994). As an approach, it consists in estimating a general equation with a maximum number of fixed delays (here, we fix pmax $=3$, following the work done by Ozanne [2006]). Then, among the explanatory variables, the last differentiated term with the least significant coefficient is eliminated and the equation is re-estimated until all explanatory variables delayed in difference are all significant. These estimates are made by considering national per capita income as variables of interest in the ARDL relationship.

Following the strategy described, we arrive at the ARDL model $(1,2,2,0,0,2,0,0)$. The results of the estimates indicate that the Fisher statistic obtained (3.485) is significant and higher than the upper critical value from the Pesaran table. This does not confirm, but suggests the existence of a cointegration relationship between per capita national income, foreign debt, official development assistance, domestic savings, private aid, For the selected model. Moreover, the error-correcting model validates the existence of a cointegration relation. Indeed, the term of error correction (the restoring force) is indeed negative and significant, this corroborates the existence of a long-term relation and thus allows to validate the model with error correction. On the whole, the coefficients of the explanatory variables have expected signs.

Table 3: Estimation of the ARDL error correction model $(1,2,2,0,0,2,0,0)$ (Dependent variable $\triangle$ NIPC, period: 1980-2013)

\begin{tabular}{|c|c|c|}
\hline Variables & Coefficients & Prob. \\
\hline $\operatorname{NIPC}(-1)$ & -0.0759 & $0.0017^{\star * *}$ \\
\hline ODA $(-1)$ & 5193.908 & $0.0019^{\star \star *}$ \\
\hline ODA 2(-1) & -192.8153 & $0.0443^{* *}$ \\
\hline$S A V(-1)$ & 178.9542 & 0.4576 \\
\hline $\operatorname{PDA}(-1)$ & 708.3982 & 0.1648 \\
\hline $\mathrm{FDI}(-1)$ & 44.46332 & 0.8379 \\
\hline DEBT(-1) & -68.41273 & $0.0889^{*}$ \\
\hline OPEN $(-1)$ & 390.6832 & $0.0780^{*}$ \\
\hline$\triangle$ NIPC $(-1)$ & 0.263831 & $0.0002^{* * *}$ \\
\hline$\triangle \mathrm{ODA}$ & 1103.91 & 0.4257 \\
\hline$\triangle \mathrm{APD}(-1)$ & -1858.97 & 0.2387 \\
\hline$\triangle \mathrm{ODA}(-2)$ & -4503.177 & $0.0013^{\star * *}$ \\
\hline$\triangle O D A 2$ & 12.41638 & 0.8678 \\
\hline$\triangle \mathrm{ODA} 2(-1)$ & 100.5402 & 0.2181 \\
\hline$\triangle O D A-2(-2)$ & 224.6971 & $0.0017^{* * *}$ \\
\hline$\Delta S A V$ & 955.5751 & $0.0004^{* *}$ \\
\hline$\triangle \mathrm{PDA}$ & -183.9491 & 0.6415 \\
\hline$\Delta \mathrm{FDI}$ & -209.4914 & 0.4822 \\
\hline$\Delta \mathrm{FDI}(-1)$ & 459.897 & 0.1745 \\
\hline$\Delta \mathrm{FDI}(-2)$ & -799.6374 & $0.0190^{* *}$ \\
\hline$\triangle \mathrm{DEBT}$ & 61.74545 & 0.5094 \\
\hline$\triangle \mathrm{OPEN}$ & 855.9419 & $0.0152^{* *}$ \\
\hline @trend & 1107.813 & $0.0000^{\star \star *}$ \\
\hline D1 & -29324.01 & $0.0001^{* * *}$ \\
\hline D2 & -36396.08 & $0.0000^{* * *}$ \\
\hline D4 & -39058.82 & $0.0000^{\star * *}$ \\
\hline D5 & -42605.23 & $0.0000^{\star \star *}$ \\
\hline D6 & -24654.43 & $0.0004^{* * *}$ \\
\hline D7 & -35484.29 & $0.0000^{* * *}$ \\
\hline$R^{2}=0.443149$ & $\overline{\mathrm{R}}^{2}=0.353023$ & F-statistique $(8,173)=3.485211^{* * \star}$ \\
\hline
\end{tabular}

Note: ${ }^{* * *},{ }^{* *}$ and ${ }^{*}$ significance at the threshold of $1 \%, 5 \%$ and $10 \%$

Source: Author, under stata 12 
The results of the residue diagnostic tests show that the ARDL model $(1,2,2,0,0,2,0,0)$ obtained successfully passes the various econometric tests. We can validate the models and interpret the results of the estimates.

\subsection{Interpretations of results and determination of a threshold effect}

Estimates show that in the ARDL model $(1,2,2,0,0,2,0)$, the variables APD, APD_2 and OUV are significant in level. Delayed variables of Official Development Assistance and trade openness appear to have a significant positive influence on the variation in national per capita income $(\triangle$ NIPC). The square of ODA seems to exert a negative influence as well as external debt. The other lagged variables do not have a significant effect. Differentiated variables of domestic savings and openness are considered to be statistically significant and have a positive influence on the variation in national income per capita. The two-dimensional delays in official development assistance ( $\triangle$ ODA_2 (-2)) have a positive effect on the variation in national income. In other words, its influences on national per capita income remains positive after two years.

The initial income per capita coefficient bears a negative sign in the estimated and significant model. This reflects the conditional convergence conditions verified by Barro. Thus, given the results, the convergence hypothesis in the WAEMU is accepted in the short term: the Union's initially poor economies have higher per capita growth rates than the initially rich economies. In other words, the standard of living of the various economies of the Union tends to come closer.

Most of the dummy variables are all statistically significant, reflecting the fact that each country has structural characteristics that differ from those of other countries and have a significant influence on the dependent variable.

The results of the estimates indicate the existence of a cointegration relation, this long-term relationship is reflected by the equations below. Values in parentheses represent t-statistics.

$$
\begin{aligned}
& \boldsymbol{N I P C _ { i t }}=68430.935 * \boldsymbol{O D} \boldsymbol{A}_{\mathrm{it}}-2540.386 * \mathbf{O D A 2}_{\mathrm{it}}+2357.762846 * \boldsymbol{S A} \boldsymbol{V}_{\mathrm{it}}+ \\
& (2.342913)^{* *} \quad(-1.749623)^{*} \\
& \text { (0.733550) } \\
& 9333.309 \text { * } \text { PDA }_{i t}+585.8145{ }^{*} \text { FDI }_{i t}-901.35 \text { * } \text { DEBT }_{i t}+5147.341{ }^{*} \mathbf{O P E N}_{i t}+\varepsilon_{i t} \\
& (-1.557689) \\
& (2.176662)^{* *}
\end{aligned}
$$

This long-term relationship shows that official development assistance and its square have a negative impact on economic growth in WAEMU countries. The result is the significance of the official development aid variable and its square, but also the opposite signs of their coefficients. As far as trade openness is concerned, an intensification over time of the Union's trade with the outside world would fuel the economic growth of the WAEMU. The efficiency of the export sectors of the countries ensures economic prosperity. The degree of trade openness generally affects economic growth in a positive and meaningful way. Indeed, it allows the economy to benefit not only from technological transfers but also, and above all, from its various forms of positive externalities and from the effects of external demands.

The contrary impact of Official Development Assistance and its square on the economic growth of the WAEMU leads to the determination of an optimal level of public support needed to boost the growth of the WAEMU countries, about the recommendations made at the Monterrey conference (that is, including domestic savings, private assistance and Foreign Direct Investment in the model).

Thus, on the basis of the long-run relationship, the derivative of national per capita income from official development assistance, we obtain:

$$
\frac{\partial N I P C_{i t}}{\partial O D A_{i t}}=68430.935-5080.772 * O D A_{i t}
$$

At the optimum $\frac{\partial N I P C_{i t}}{\partial O D A_{i t}}=0$, which implies $O D A_{i t}=13.5$

The optimal threshold for public support needed to boost the growth of WAEMU countries is $13.5 \%$ of GDP per capita for the sample under the assumption of implementation of the recommendations made at the Conference in Monterrey. 


\section{Conclusion}

The aim of this paper is to verify empirically from an econometric approach the impact of official development assistance on the growth of WAEMU member countries. This assessment builds on the recommendation of the 2002 Monterrey conference on diversification of development support resources.

The evaluation was carried out using an ARDL panel model and the cointegration approach according to Pesaran et al (2001). The results indicate that, in the short and long term, public aid has a positive impact on growth.

Econometric estimates have indicated the opposite impact of official development assistance and its square on WAEMU's economic growth. This led to the determination of an optimal level of public support needed to boost the growth of WAEMU countries. This threshold is $13.5 \%$ of GDP per capita.

\section{References}

Adam, C.S. and S.A. O'connell. (1997), "Aid, Taxation and Development: Analytical Perspectives on Aid Effectiveness in Sub-Saharan Africa", WPS / 975, Center for the Study of African Economies, University of Oxford, St Cross Building, Manor Road, Oxford OX13UL

Ahmed, M.Q. (1992), Foreign Aid, Domestic Savings and Economic Growth: The Case of Assemien, A. (1994), "Debt and Growth: The Case of Côte d'Ivoire", Economic Policy Analysis Unit of Cires (CAPEC), Working Paper (D.T.) No. 2.

Assemien, A. (1996), "Policy for the Promotion of National Saving and Investment Financing in Côte d'Ivoire", Economic Policy Analysis Unit of CIRES (CAPEC), Working Document (DT) N ${ }^{\circ} 28$.

Baltagi B.H (1995), Econometric Analysis of Panel Data, John Wiley \& Son, New York.

Caceres, L.R. (1995), "Foreign Resources, Domestic Savings and Economic Growth: The Case of Central America", Savings and Development, No. 4-XIX, pp393-403.

Campbell, R. (1999), "Foreign Aid, Domestic Savings and Economic Growth: Some Evidence From the ECCB Area", Savings and Development, No. 3-XXIII, pp.225-77.

Chenery, H.B. and A.M. Strout. (1966), "Foreign Assistance and Economic Development", The American Economic Review, Vol. LVI, No. 4, pp. 679-733.

Cohen, M. and J. Pradel. (1993), Econometrics, Litec Edition, Paris.

Griffin, K. (1970), "Foreign Capital, Domestic Savings and Economic Development", Bulletin of the Oxford University Institute of Economics and Statistics, vol.32, pp.99-112.

Griffin, K. (1973), "The Effect of Aid and Other Resource Transfers on Savings and Growth in Less-Developed Countries: A Comment", Economic Journal, Vol.83, pp.863-66.

Gujarati, D.N. (1988), Basic Econometrics, McGraw-Hill Book Company, New York.

Gupta, L.K. and Mr. A. Islam. (1983), Foreign Capital, Savings and Growth, D. Reidel Publishing Company, Dordrecht, Holland.

Hsiao, C. (1986), "Analysis of Panel Data", Econometric Society Monographs No. 11.Cambridge University Press.

Islam, A. (1992), "Foreign Aid and Economic Growth: An Economic Study of Bangladesh", Applied Economics, Vol. 24, pp. 541-44.

Johnston, J. (1988), Econometric Methods, Tomes 1 and 2, 3rd Edition, Economica Edition.

Khan, H.A. and E. Hoshino. (1992), "Impact of Foreign Aid on the Fiscal Behavior of LDC Governments", World Development, Vol. 20, No. 10, pp1481-88.

Krishnamurty, I. (1968), "Savings and Taxation in Developing Countries: An Empirical Study", International Bank for Reconstruction and Development, Economic Department, Paper No. 23.

Levy, V. (1984), "The Savings Gap and the Productivity of Foreign Aid to a Developing Economy: Egypt", The Journal of Developing Areas, Vol.19, pp. 21-34.

Levy, V. (1987), "Does Concessionary Aid Lead to Higher Investment Rates in Low-Income Countries?", The Review of Economics and Statistics, vol.69, pp152-56.

Levy, V. (1988), "Aid and Growth in Sub-Saharan Africa: The Recent Experience", The European Economic Review, vol.32, pp1777-95.

Mavrotas, G. and R. Kelly. (2001), Savings Mobilization and Financial Sector Development: The Nexus, Savings and Development, No. 1, XXV, pp33-66

Mckinnon, R.I. (1964), "Foreign Exchange Constraints in Economic Development, and Efficient Aid Allocation", Economic Journal, Vol.74, pp388-409.

Mosley, P., J. Hudson and S. Horrell. (1987), "Aid, the Public Sector and the Market in Less Developed 
Countries", The Economic Journal, Vol.97, pp616-641.

Papanek, G. (1972), "The Effects of Aid and Other Resources Transfers on Savings and Growth in Less Developed Countries", Economic Journal, Vol.82, pp934-50.

Pesaran, M. H., Y. Shin, and R. J. Smith (2001), Bounds Testing Approaches to the Analysis of Level Relationships. Journal of Applied Econometrics, 16, 289-326.

Rahman, M.A. (1984), Foreign Aid and Self-Reliant Growth: the Case for Bangladesh, Center for Social Studies, Dhaka University.

Rana, P.B. (1987), "Foreign Capital, Exports, Savings and Growth in the Asian Region", Savings and Development, No. 1, XI, pp. 5-27.

Reichel, R. (1995), "Development Aid, Savings and Growth in the 1980s: A Cross Section Analysis", Savings and Development, No. 3-XIX, pp279-96.

Shan, J. and F. Sun (1998), Domestic Saving and Foreign Investment in Australia: a Granger Causality Test. International Economic Journal, 12, 79-87.

Romer, D. (1997), Advanced Macroeconomics, MacGraw-Hill / Ediscience International, Paris.

Sahoo, P .; G. Nataraj and B. Kamaiah. (2001), "Savings and Economic Growth in India: The Long Run Nexus", Savings and Development, No. 1-XXV, pp67-80.

Taslim, M.A. and A. Weliwita. (1998), "Investment, Saving, Aid and Entrepreneurship", unpublished paper.

White, H. (1992), "The Macroeconomic Impact of Development Aid: A Critical Survey", The Journal of Development Studies, Vol.28, No. 2, pp163-240.

Weisskopf, T.E. (1972), "The Impact of Foreign Capital Inflow on Domestic Savings in Underdeveloped Countries", Journal of International Economics, Vol.2, pp.25-38.

Younger, S.D. (1992), "Aid and the Dutch Disease: Macro-Economic Management When Everybody Loves You", World Development. 